\title{
KAMPANYE IKLAN LAYANAN MASYARAKAT PRODUKSI PNRI
}

\author{
Laksmi
}

\begin{abstract}
This study examines the message of the public services announcement (PSA) produced by PNRI. The PSA are supposed to encourage audiences to read books to improve their live. Indonesian society is known as oral tradition, meanwhile, reading habit helps people develop a critical thinking. I use qualitative approach to analyze dialogues, characters, virtual images, and information. The aim of the study is to understand how PSA is produced, communicated, and consumed by people. This research analyses meaning construction of reading and its relevance to welfare. I collect the data from seven PSA and analyze them by critical discourse analysis method.

The first finding is that people understand partially the message: they understand that library and reading are important for their life. But they do not understand the relevancy between reading and improving their live. Second finding, most of society belief that they learn knowledge not necessary from the books, but they can gain it from parents, friends, religion, and television. Meanwhile, PSA reveals social reality that there are different values between society and PNRI. The contradictions of values become barriers to deliver the message of the importance of reading. The recommendation for it is to improve technique of campaign.
\end{abstract}

\section{Keywords}

PSA, reading habit, library.

\section{PENDAHULUAN}

Penelitian ini bertujuan untuk menjelaskan proses Iklan Layanan Masyarakat (ILM) buatan Perpustakaan Nasional Republik Indonesia (PNRI) diproduksi, disampaikan, dan dikonsumsi oleh masyarakat. Iklan layanan masyarakat yang mengampanyekan upaya meningkatkan taraf hidup masyarakat sudah banyak dilakukan di Indonesia, misalnya kampanye antinarkotika, kampanye tanggap flu burung, imunisasi dan imbauan untuk menabung. Semua jenis ILM tersebut dimaksudkan untuk membuka kesadaran masyarakat akan kehidupan, sehingga mereka dapat memutuskan segala sesuatu yang terbaik untuk meningkatkan taraf hidup.

Salah satu iklan layanan masyarakat di bidang pendidikan adalah iklan yang diproduksi oleh PNRI. Berdasarkan proses produksi, iklan-iklan tersebut membawa pesan tentang pentingnya membaca dan mempromosikan keberadaan PNRI. Tujuh 
buah iklan yang dibuat antara tahun 2004 dan 2008 tersebut, diberi judul seri Cara Pintar Buat Pintar. PNRI sebagai lembaga pemerintah nondepartemen dan bergerak di bidang perpustakaan dan informasi, menunjukan tanggung jawab atas minat dan kebiasaan membaca masyarakat Indonesia masih kurang. International Educational Achievement yang membuat penelitian tentang kemampuan membaca siswa di kawasan ASEAN pada tahun 2004, menunjukkan bahwa Indonesia menempati urutan ke-38 dari39 negara. Selain itu, keberadaan perpustakaan juga kurang diminati oleh masyarakat, termasuk oleh remaja (Kompas, 2002; Harian Terbit, 2006). Padahal kegiatan membaca pada hakikatnya adalah kegiatan yang dapat melatih daya analisis dan mengembangkan cara berpikir kritis (Elkin 2003, 12-3). Daya tersebut mendorong manusia berpikir kreatif untuk dapat memberdayakan diri sendiri dalam upaya meningkatkan taraf hidup, menambah wawasan, memperkaya imajinasi, memunculkan dampak terapis, serta menumbuhkan kemampuan bersosialisasi, dan kesadaran budaya.

Secara praktis, tujuan penelitian ini adalah memberikan kontribusi dalam produksi ILM di masa datang oleh PNRI agar dapat mencapai tujuannya secara maksimal. Secara akademis, manfaat penelitian ini adalah untuk memberi wawasan lebih luas pada bidang kajian perpustakaan dan informasi dalam memaknai ILM di bidang kepustakawanan.

\section{MEMAHAMI IKLAN LAYANAN MASYARAKAT}

Gagasan utama munculnya sebuah iklan adalah upaya memotivasi dan memengaruhi publik untuk menggunakan atau membeli produk, ataupun menggunakan jasa yang ditawarkan. Selain itu, iklan juga ditujukan untuk mempengaruhi pendapat publik untuk berpikir dan bertindak sesuai dengan keinginan si pemasang iklan (Lee \& Johnson 1999, 170). Salah satu jenis iklan adalah ILM, yang bertujuan untuk memenuhi kepentingan masyarakat dan mempromosikan kesejahteraan masyarakat. Iklan merupakan artefak yang perlu dipahami secara kultural, sebab iklan dianggap sebagai medium kebudayaan (Gay 1997, 2; Askew 2002, 18). ILM merupakan hasil konstruksi budaya yang berkaitan dengan proses representasi, proses produksi, dan juga proses implementasinya di masyarakat. Sebuah iklan umumnya menggunakan simbol yang dipahami bersama berdasarkan moral, nilai, dan aturan sosial. Simbol yang dapat berupa bahasa, kata, gambar, ikon, dan suara, termasuk gerak tubuh, jargon, lagu, humor, gosip, metafora, slogan, adalah sesuatu yang diberi makna secara berbeda dari objek itu sendiri, dan hanya dipahami oleh kelompok masyarakat yang menggunakannya.

Dalam mengonstruksi realitas sosial, setiap individu akan memberi makna yang berbeda-beda terhadap suatu simbol, karena setiap individu memiliki latar belakang yang berbeda, seperti pengalaman, pendidikan, preferensi, dan lingkungan sosial. Oleh karena itu, ketika individu menafsirkan simbol, kemudian menyerapnya ke dalam kesadaran, ia akan memaknainya secara subjektif. Dengan demikian, memahami kebudayaan masyarakat sebagai target pemirsa merupakan hal yang utama dalam 
sebuah kegiatan kampanye (Lee \& Johnson 1999, 175). Proses interaksi yang terjadi antara teks iklan, pembuat iklan, pihak televisi, dan masyarakat, memungkinkan mereka saling menginterpretasi dan memaknai tindakan mereka.

Penelitian tentang iklan telah banyak dilakukan dari berbagai macam perspektif. Sebagian besar dari penelitian tersebut menggunakan perspektif ilmu manajemen, yang berfokus pada dampak iklan terhadap perubahan perilaku masyarakat. Sementara itu penelitian lain yang menggunakan perspektif budaya, cenderung lebih berfokus pada proses munculnya sebuah iklan, mulai dari produksi, penyampaian, hingga penerimaannya di masyarakat.

\section{RUMUSAN MASALAH DAN PERTANYAAN PENELITIAN}

Menyampaikan informasi yang bersifat abstrak, seperti makna keadilan, kasih sayang dan kebajikan, merupakan pekerjaan yang sulit. Demikian pula dengan menyampaikan tentang manfaat informasi bahwa membaca itu dapat meningkatkan taraf hidup. Durasi ILM PNRI rata-rata sepanjang 30 hingga 60 detik dan ditayangkan selama 2 minggu hingga 1 bulan di empat stasiun televisi: TVRI, RCTI, SCTV, dan MetroTV. ILM produksi PNRI dilabeli dengan nama seri Cara Pintar Buat Pintar, terdiri atas tujuh seri (Lihat Bagan 1). Setiap seri menggunakan metode yang berbeda, misalnya seri Dady, yang dibuat dengan pendekatan keluarga dan kesadaran akan kelas sosial dan seri Kiwil yang dibuat dengan teknik animasi.

Berdasarkan latar belakang di atas, yang menjadi pertanyaan dalam penelitian ini adalah apakah pesan ILM tersebut dipahami oleh pemirsa dengan makna yang sama dengan yang dimaksudkan oleh PNRI? Pertanyaan tersebut diuraikan ke dalam dua bagian, yaitu bagaimana proses pemahaman pemirsa terhadap iklan tersebut dan realitas sosial apa yang sebenarnya disampaikan oleh ILM, mencakup makna atau pesan, nilai, norma, dan keyakinan yang disampaikan oleh pembuat iklan tersebut.

\section{METODE PENELITIAN}

Melalui penelitian kualitatif ini, ketujuh iklan tersebut dianalisis dengan menggunakan analisis wacana kritis Norman Fairclough, berdasarkan tiga tataran peristiwa komunikasi, yaitu tataran teks; tataran praktik wacana; dan tataran praktik sosiokultural (Fairclough 1995, 57-62). Analisis tataran teks yang digunakan adalah metode van Dijk, dengan elemen yang terdiri atas struktur makro (analisis makna dengan melihat aspek tematik); superstruktur (analisis aspek skematik teks), dan struktur mikro (analisis aspek semantik, sintaksis, stilistik, dan retoris). Dalam tataran praktik wacana, makna dilihat dari proses produksi dan konsumsi teks, yang mencakup karakteristik dan latar belakang penciptaannya, gaya penyajian, struktur industri media, sedangkan konsumsi teks meliputi bagaimana masyarakat menginterpretasi, merespons, dan memahami teks iklan. Dalam tataran praktik sosiokultural, analisis meliputi konteks sosial-budaya 
dari masyarakat sasaran. Analisis juga menggunakan metode intertekstualitas, dengan menganalisis pendapat atau opini masyarakat yang ada dalam artikel di media cetak dan elektronik. Teknik pengumpulan data dilakukan dengan pengamatan dan wawancara. Dalam kegiatan wawancara, native's point of view dari para informan, yaitu penduduk di wilayah Depok dan berusia setara dengan usia siswa menengah pertama ke atas, muncul secara alamiah. Informan juga mencakup staf yang terlibat dalam proses produksi ILM.

\section{HASIL DAN PEMBAHASAN}

a. Analisis teks

Dari struktur makro, terlihat ketidak konsistenan antara judul seri dan pesan dalam ILM. Judul seri Cara Pintar Menjadi Pintar diinterpretasikan sebagai cara yang disarankan untuk menjadi pintar, yaitu dengan cara meminjam buku di perpustakaan. Di sana, kita bisa memperoleh pengetahuan dengan mudah, tanpa mengeluarkan uang banyak bahkan dapat menghemat tenaga. Seri Presiden SBY dan Tantowi mendukung pernyataan sadar akan perpustakaan. Seri Dady Rahmananta memberi contoh penghematan, bagaimana masyarakat dapat membaca buku di perpustakaan tanpa mengeluarkan uang untuk membelinya. Dalam seri Bajuri-Oneng, Tantowi, dan Kiwil, dipermudah oleh perpustakaan keliling yang mendatangi kediaman kita.

Sementara itu, pesan yang disampaikan oleh ILM adalah bahwa kita dapat menjadi sukses karena membaca. Faktanya, sebagian besar masyarakat Indonesia, yang dikenal sebagai masyarakat budaya lisan, akan berpikir, untuk apa ke perpustakaan? Bagi mereka, kegiatan membaca tidak jelas tujuannya dan tidak ada manfaatnya untuk kehidupan nyata, jadi mereka tidak merasa perlu datang ke perpustakaan.

Penyimpangan pada tema utama muncul pada seri-seri berikut ini. Pada seri Kiwil, frasa Cara Pintar Menjadi Pintar tidak dijadikan judul seri, padahal substansinya merujuk pada makna frasa tersebut. Judul serinya yang bertajuk Undang-undang, tidak mencerminkan substansi tentang undang-undang perpustakaan, tetapi lebih kepada pesan bahwa undang-undang tersebut menjamin rakyat akan eksistensi perpustakaan. Sebaliknya, dalam seri Marshanda, eksistensi perpustakaan tidak penting, sebab membaca dapat di mana saja. Berdasarkan adegan dalam ILM, di mana saja dimaksudkan sebagai tempat apapun seperti bisa di tempat shooting, di kafe, dan tempat lain.

Dari superstruktur, skema merujuk pada urutan cerita, adegan yang didahulukan dan yang harus disembunyikan untuk mendukung tema utama. Pada seri Bajuri-Oneng, Tantowi, Tukul, Dady, dan Kiwil, adegan yang ditonjolkan adalah penggambaran sekelompok masyarakat kelas menengah dan menengah bawah yang menyadari pentingnya perpustakaan. Namun, pada seri Tamara, nuansa yang ditonjolkan berbeda. Adegan pertama yang terasa unik adalah suara latar dari seorang pria yang mengatakan bahwa "Tamara diam-diam mempunyai teman akrab." Yang dimaksud sebagai teman akrab adalah buku, tetapi adegan tersebut dapat dimaknai lain. Tamara yang waktu 
iklan ditayangkan berstatus janda dan tubuhnya yang seksi dengan pakaian kasual yang ketat, dengan nada suara lemah lembut dan selalu tersenyum, menimbulkan makna lain bagi istilah 'teman akrab'. Namun bisa jadi 'makna lain' tersebut menimbulkan emosi lebih dalam, seperti perasaan empati, sehingga iklan tersebut lebih lama diingat (Lee \& Johnson 1999, 136).

Narasi pada sebagian besar ILM PNRI menunjukkan urutan alur cerita yang melompat-lompat dan kaitan yang antaradegan yang tidak jelas. Cara penyajian tema pokok dalam urutan alur cerita yang melompat, seperti dalam seri Bajuri-Oneng, Marshanda, Tantowi, Tukul, dan Kiwil, kurang dapat menyajikan alur cerita yang utuh dan runtun. Contoh yang jelas adalah seri Tukul. Ia dikenal karena kisah kariernya yang dimulai dari bawah, saat pertama kali masuk grup Srimulat, hingga ia memiliki acara sendiri Bukan empat mata. Kariernya yang terus menanjak diyakini oleh para informan adalah karena kerja kerasnya, bukan karena membaca buku. Demikian pula dengan Marshanda, yang memiliki karier yang makin lama makin bersinar. Sayangnya, proses mereka menjadi sukses tidak dijelaskan secara rinci.

Garin, sutradara film ternama mengkritik seri Kiwil yang terlalu banyak insert, terputus-putus, sehingga alur cerita tidak sepenuhnya mengalir. Seri dengan judul Undang-undang memang satu-satunya seri yang membahas tentang hukum. Adanya undang-undang perpustakaan yang menjadi payung hukum tentunya mendukung kepentingan masyarakat akan ketersediaan dan akses informasi di perpustakaan. Bagi masyarakat yang tidak mampu mengenyam pendidikan formal, mereka dijamin oleh pendidikan otodidak dan seumur hidup yang ditawarkan oleh perpustakaan.

Dari struktur mikro, analisis menekankan pada semantik, sintaksis, stilistik, dan retorisnya. Alasan dipilihnya artis-artis yang sedang naik daun, adalah untuk menarik perhatian masyarakat. Hal tersebut menunjukkan bahwa kepentingan promosi PNRI lebih menonjol dibandingkan pesan utama. Presiden SBY juga dijadikan sebagai penguat dukungan bagi PNRI. Tim pembuat ILM kurang mempertimbangkan apakah para artis tersebut benar-benar senang membaca atau tidak, kecuali Rieke dan Tantowi. Sementara itu, lokasi tempat iklan diproduksi didominasi oleh PNRI, kecuali versi Marshanda dan Kiwil yang berlokasi di taman bacaan. Dari segi sintaksis, dialog para tokoh dengan kalimat-kalimat pendek, suara lembut dan senyum ramah, membujuk publik untuk membaca dan datang ke perpustakaan. Para artis menggunakan kata aku dan saya dan kata ganti kita dengan maksud melibatkan diri dengan masyarakat, menumbuhkan solidaritas, dan menghilangkan jarak (Eriyanto 2001, 254). Kecuali seri Bajuri-Oneng yang memang ingin menonjolkan tradisi Betawi, mereka menggunakan kata $l u$, untuk lawan bicara. Berikut adalah rincian dialog dan alur cerita di setiap versi:

Alur cerita dan dialog para tokoh berdasarkan Struktur mikro semantik 


\section{CONTOH 1}

\section{TOKOH}

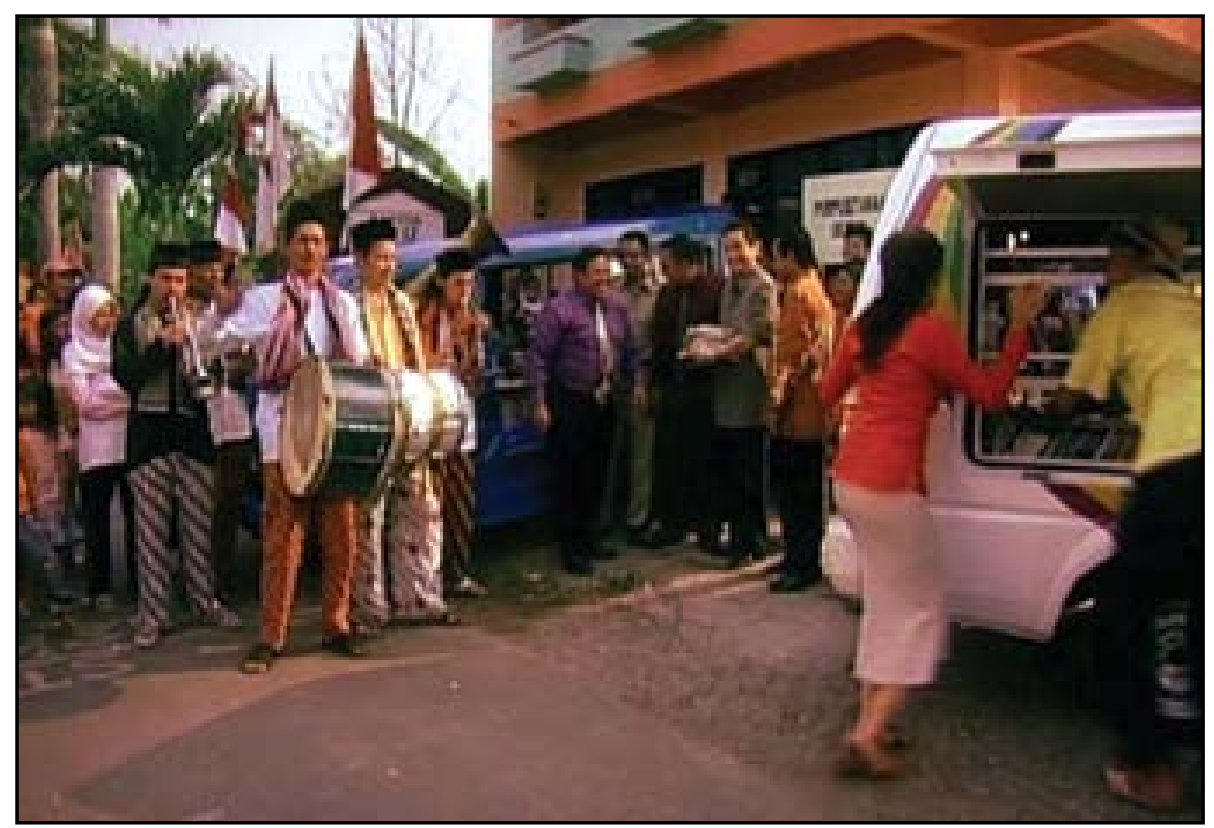

Bajuri dan Oneng, atau Mat Solar dan Rieke Dyah Pitaloka, 2006

\section{ADEGAN DAN DIALOG}

Adegan 1:

Bajuri dan Oneng duduk bertiga di bagian depan, di sebuah angkot. Bajuri mengenakan hem biru muda dengan dasi merah, dan Oneng mengenakan blus merah dengan rok merah muda. Bajuri memangku setumpuk buku yang diikat tali rafia. Mereka berada di lingkungan perumahan. Di sekitar mereka, masyarakat, tua dan muda, berjalan kaki menuju arah yang sama. Di antara mereka ada seorang pria buta menumpang becak, menggunakan kacamata hitam dan memegang tongkat.

Supir: "Pade mau kemana lagi nih bang?"

Oneng: "Mau ade acara apaan sih bang ? Bawa buku banyak banget." Di bagian belakang angkot, terdapat tumpukan buku juga.

Bajuri: "Liat aja sendiri dah."

Oneng: "Pade mau kemana sih nih orang-orang?"

Bajuri: "Ke perpustakaan."

Oneng dan supir berbicara bersama: “Ke perpustakaan?"

Bajuri: "He - eh."

Adegan 2:

Pak Lurah berdiri di depan PNRI, di samping mobil perpustakaan keliling: “Dengan perpustakaan keliling, buku datang ke kita. Hari lain, kita bisa ke perpustakaan sendiri. Kita harus rajin baca." 


\section{Adegan 3:}

Oneng dan Bajuri turun dari angkot. Mereka ada di halaman parkir PNRI. Bajuri menyerahkan satu ikat buku kepada empat petugas. Kemudian keempat petugas itu menurunkan buku-buku dari angkot. Mereka juga disambut oleh sekelompok orkes tanjidor. Musik Betawi mengiringi seluruh film. Oneng berdiri di depan perpustakaan keliling. Di sekelilingnya ada beberpa orang yang sedang membaca sambil berdiri. Ia melambaikan tangan memanggil Bajuri: "Sini."

Bajuri mendekati Oneng: "Ini mobil perpustakaan cakep banget. Ini Lurah yang bikin?” Bajuru: "Lurah? Ini bantuan pemerintah, dari PNRI."

Oneng: "O iye, ye?"

Bajuri: "Jadwalnya lagi ada di sini. Tuh, lo lihat. Masyarakat kite makin lama makin pinter. Makanya perpustakaan harus ada di mana-mana."

Oneng: "Biar nggak oon lagi ye?"

Bajuri: “Biar nggak kayak lo." Bajuri membawa sebuah buku berjudul Beternak Itik Tanpa Air. Oneng juga membawa buku, tetapi hanya terlihat sampul belakangnya.

Oneng: "Perpustakaan, cara pinter, ..."

Bajuri: "buat pinter."

Oneng: "Iye bener, iye..."

\section{INTERPRETASI}

1. Semantik: PNRI merupakan lembaga besar di Indonesia, memiliki kepentingan untuk dikenal masyarakat. Iklan lebih menonjolkan detil lokasi; tokoh artis yang sedang naik daun sebagai alat untuk menarik perhatian masyarakat.

2. Sintaksis: Penggunaan kalimat persuasif mengajak masyarakat membaca dan datang ke perpustakaan: penggunaan 'kita'.

3. Stilistik:

- PNRI ingin menunjukkan bahwa lembaga tersebut untuk semua lapisan masyarakat, terlihat dalam pilihan kata-kata Betawi.

- Daya tarik humor untuk menimbulkan perasaan gembira.

4. Retoris:

- Pengambilan gambar menunjukkan bahwa PNRI tempat bagi semua orang.

- Kamera bergerak mengikuti gerak tokoh, menggambarkan PNRI yang dinamis.

5. Pesan:

- Mengajak membaca dan datang ke PNRI.

- Membaca bisa menjadikan kita sukses.

- Perpustakaan keliling mempermudah masyarakat. 


\section{CONTOH 2}

\section{TOKOH}

Tamara Bleszynski, 2004

Di layar muncul teks, dan terdengar suara latar seorang pria: Tamara Bleszynski, diamdiam punya teman akrab.

\section{ADEGAN DAN DIALOG}

Adegan 1:

Di ruang baca PNRI: Tamara yang memakai kaos merah muda dan celana jeans, keluar dari balik rak buku sambil membawa buku biru, berjalan perlahan, dan berkata: "Benar, buku. Dia selalu menemani saya, kapan saja, dan di mana saja. Dengan membaca, ilmu pengetahuan kita bertambah, kreativitas kita juga bertambah ..." Kamera bergerak mengikuti objek.

Adegan 2:

Ia berhenti di salah satu meja baca, dengan latar belakang orang-orang yang sedang membaca di meja baca besar: “... dan membuat kita tertawa gembira. Dengan membaca, kita bisa menjelajahi dunia, karena buku adalah jendela dunia."

Adegan 3:

Tamara seolah-olah berdiri di lapangan parkir dekat air mancur PNRI: "Kalau saja kita mau, pasti kita mampu. Baca yuk."

Gambar terlihat seperti tidak alamiah, menggunakan teknik cropping.

\section{INTERPRETASI}

1. Semantik: PNRI merupakan lembaga besar di Indonesia, memiliki kepentingan untuk dikenal masyarakat. Iklan lebih menonjolkan detil lokasi; tokoh artis yang sedang naik daun sebagai alat untuk menarik perhatian masyarakat.

2. Sintaksis: Penggunaan kalimat persuasif mengajak masyarakat membaca dan datang ke perpustakaan. Koherensi tidak ada: “... di mana saja," tetapi gambar menunjukkan tokoh ada di perpustakaan.

3. Stilistik: penggunaan istilah teman akrab, tertawa bersama, dan baca yuk, ingin mengungkapkan bahwa mem-baca adalah suatu kegiatan yang menyenangkan.

4. Retoris:

-PNRI ingin menunjukkan bahwa lembaga tersebut untuk semua lapisan masyarakat, terlihat dalam pilihan kata-kata Betawi.

- Daya tarik humor untuk menimbulkan perasaan gembira.- Kaos merah muda ketat dan jeans yang dikenakan artis menjadi ikon gaya hidup kosmopolitan.

5. Pesan: Mengajak membaca dan datang ke PNRI. 


\section{CONTOH 3}

\section{TOKOH}

Presiden SBY dan Tantowi Yahya, 2004

\section{ADEGAN DAN DIALOG}

\section{Adegan 1:}

SBY sedang berpidato: "PNRI harus dapat menjadi pelopor dalam mewujudkan masyarakat Indonesia yang sadar perpustakaan." PNRI ingin menunjukkan bahwa presiden sebagai pemimpin bangsa mendukung peran PNRI dalam mewujudkan masyarakat yang sadar akan perpustakaan.

Di latar belakang muncul tulisan pelopor sadar perpustakaan. Di layar, muncul mobil perpustakaan keliling yang datang ke sekolah menengah pertama. Murid-muridnya sangat antusias menyambut kedatangan mobil perpustakaan keliling tersebut dan mereka langsung mencari dan membaca buku dari mobil tersebut.

\section{Adegan 2:}

Dady P. Rachmananta berdiri di ruang baca perpustakaan, sambil membawa sebuah buku terbuka. Ia berkata: "Saya setuju akan pendapat Bapak Presiden dan perpustakaan adalah wahana belajar sepanjang hayat." Di sini Dady menegaskan bahwa PNRI adalah sebuah wahana untuk belajar bagi semua lapisan masyarakat dan dapat digunakan seumur hidup. Pada latar belakang muncul tulisan yang mendukung, yaitu 'wahana belajar'.

Adegan 3:

Tantowi Yahya duduk di perpustakaan sambil membuka-buka buku. Di sekelilingnya tampak banyak pengunjung dari berbagai usia, mulai pelajar sampai orang tua. Ia berkata: "Generasi sukses generasi membaca." Di layar muncul tulisan yang berbunyi 'generasi sukses'.

Adegan 4:

Setelah bagian Tantowi Yahya selesai, pada bagian ini muncul tulisan 'cara pintar buat pintar' dengan didukung oleh tiga model mahasiswa yang melempar buku ke atas sambil meloncat, dan ketika buku jatuh, buku berubah menjadi toga dan mereka pun tiba-tiba mengenakan pakaian wisuda, simbol seorang sarjana, atau kondisi sukses.

\section{INTERPRETASI}

1. Semantik: Penggunaan tokoh presiden menunjukkan bahwa PNRI dekat dengan pusat kekuasaan. Penekanan pesan lebih banyak ke kegiatan belajar.

2. Sintaksis: Penggunaan kalimat persuasif mengajak masyarakat membaca dan datang ke perpustakaan: penggunaan 'kita'.

3. Stilistik: Pilihan kata'generasi dan sepanjang hayat', menekankan bahwa membaca 
merupakan kegiatan yang dilakukan terus-menerus.

4. Retoris: Gambar yang ditonjolkan adalah gambar para pelajar dan mahsiswa, seolah-olah perpustakaan hanya untuk mereka yang berpendidikan.

5. Pesan: mengajak membaca dan datang ke PNRI.

\section{CONTOH 4}

\section{TOKOH}

Marshanda dan anak-anak di taman bacaan, 2004

\section{Adegan 1:}

Marshanda sedang membaca buku di perpustakaan, dengan latar belakang papan bertuliskan: 08.00 Perpus. Campuss. Ia berkata: "Mau tahu cara pinter buat pinter?"

Adegan 2:

Ia baru saja menyelesaikan adegan di lokasi syuting, lengkap dengan kameraman, penata cahaya, sutradara yang berteriak: “Cut. Oke, bagus." Marshanda, dengan dandanan selebriti yang glamor, mengambil break shooting dan memilih membaca buku, daripada mengobrol: "Di mana pun, aku selalu baca buku."

Adegan 3:

Dengan pakaian kasual khas remaja, ia digambarkan sedang membaca bersama sekelompok anak di Pondok Pustaka: "Siapa saja harus gemar membaca." Lalu ia membagi-bagikan buku kepada anak-anak.

Adegan 4:

ia sedang membaca di sebuah cafe, di atas meja terdapat hamburger dan jus: "Membaca bisa di mana saja."

Adegan 5:

ia mengambil buku di rak koleksi sebuah perpustakaan: "Mau tahu rahasia sukses? Selalu belajar dan rajin baca."

\section{INTERPRETASI}

1. Semantik: s.d.a Lihat halaman 82.

2. Sintaksis: s.d.a Lihat halaman 82.

3. Retoris:

- pengambilan gambar sangat dinamis, dan adegan bisa menunjukkan kegiatan artis remaja yang padat, sekaligus gaya hidup remaja.

- Selain itu, gambar menunjukkan gambar para pelajar dan mahsiswa, seolaholah perpustakaan hanya untuk mereka yang berpendidikan.

- Marshanda menjadi ikon gaya hidup kosmopolitan.

4. Pesan: mengajak membaca. 


\section{CONTOH 5}

Tukul Arwana, 2006

\section{ADEGAN DAN DIALOG}

Adegan 1:

Tukul, berpakaian kaos oblong, menekankan pesan status sosial bahwa ia datang dari masyarakat kelas bawah, turun dari angkutan kota untuk membaca buku di PNRI. Ia merogoh kantongnya, menghitung sebentar, lalu memberikannya kepada supir. Di genggaman supir, ada empat uang receh senilai seratus rupiah.

Supir: "Hi, Mas, ongkosnya kurang."

Tukul: "Mas, utang dulu ya." Ia melambaikan tangan selamat tinggal, lalu cepat-cepat pergi.

Supir: "Ya ampun, kebangetan banget ah."

Kamera meng-close-up nama Perpustakaan Nasional RI di dinding paling atas gedung.

Adegan 2:

Di depan rak bertuliskan Referensi, Tukul membaca dengan serius, bukunya berjudul Mengubah Takdir.

Adegan 3:

Tukul datang kembali ke PNRI dengan naik mobil pribadi dan supir, berpakaian jas dan dasi. Ia membawa buku berjudul, Optimislah, Anda Memiliki Semuanya.

Supirnya menyambut, ia turun dari mobil berwarna hitam: “Buku baru lagi, pak?"

Tukul: "Yo iki, mau ndak mau, aku membaca. Tapi memang hobiku sejak dulu membaca. Aku orang ndeso, katrok. Aku ingin pinter seperti ini ya karena mbaca." Lalu sambil naik ke mobilnya dan menyentuh punggung si supir, ia berkata: "Makanya senang baca." Ia duduk di dalam mobil, lalu menghadap ke kamera dan berkata: "Cara pinter buat pinter, ya mbaca. Oke?" Ia mengacungkan ibu jari.

\section{INTERPRETASI}

1. Semantik: s.d.a Lihat halaman 82.

2. Stilistik:

- s.d.a Lihat halaman 82.

- daya tarik humor untuk menimbulkan perasaan gembira.

3. Retoris: pengambilan gambar sederhana, tidak banyak menggunakan trik kamera dan pengaturan angle.

4. Pesan:

- dengan membaca, orang menjadi sukses dan kaya

- mengajak membaca dan datang ke PNRI. 


\section{CONTOH 6}

\section{TOKOH}

Dady Rahmananta 2007

\section{ADEGAN DAN DIALOG}

Adegan 1:

Layar menunjukkan perumahan kumuh di tepi sungai.

Suara latar: Gadis ini membutuhkan buku.

Di dalam rumah sederhana keluarga kelas menengah ke bawah: seorang gadis remaja sedang bercakap-cakap dengan ibunya.

Gadis: "Bu, minta uang buat beli buku dong."

Ibu: "Ibu kagak punya duit nak."

Si Gadis menunjukkan wajah kecewa: "Ya udah." Lalu ia mencium tangan ibunya, pamit akan keluar.

Suara latar seorang pria: Tetapi ada daya orangtuanya tidak punya uang. Perpustakaan adalah jalan keluarnya. Di perpustakaan, buku yang diinginkan, bisa diperoleh.

Adegan 2:

Lalu tanpa sengaja di jalan, gadis itu melihat poster yang tertempel di dinding, bertuliskan: Beli buku mahal!!! Kenapa tidak ke PNRI aja? Bisa baca di tempat. Bagian kata perpustakaan bertinta merah sehingga terlihat jelas.

Adegan 3:

Ia pergi ke PNRI untuk meminjam buku berjudul: Filsafat seni. Ketika tiba di rumah, ibu menyapanya, "Eh, udah pulang." Si Gadis duduk di samping ibunya. "Gimana, udah dapet bukunya?" Dengan wajah berseri-seri, si Gadis menjawab: "Udah dapet Bu, di Perpustakaan Nasional."

Adegan 4:

Di PNRI, dengan latar belakang rak buku, sambil membawa buku yang terbuka, Daddy berkata, "Benar. Perpustakaan adalah cara pintar untuk menjadi pintar." Lalu ia mengacungkan ibu jarinya.

Suara latar: Dipersembahkan oleh Perpustakaan Nasional.

\section{INTERPRETASI}

1. Semantik: PNRI ingin memberikan kesan bahwa lembaga mempermudah masyarakat kelas bawah.

2. Stilistik: s.d.a Lihat halaman 82.

3. Sintaksis: tokoh dari masyarakat biasa, sesuai dengan isi pesan dan sasaran yang sudah direncanakan.

4. Retoris : gambar yang ditonjolkan adalah gambar mahasiswa. 
5. Pesan: mengajak membaca.

CONTOH 7

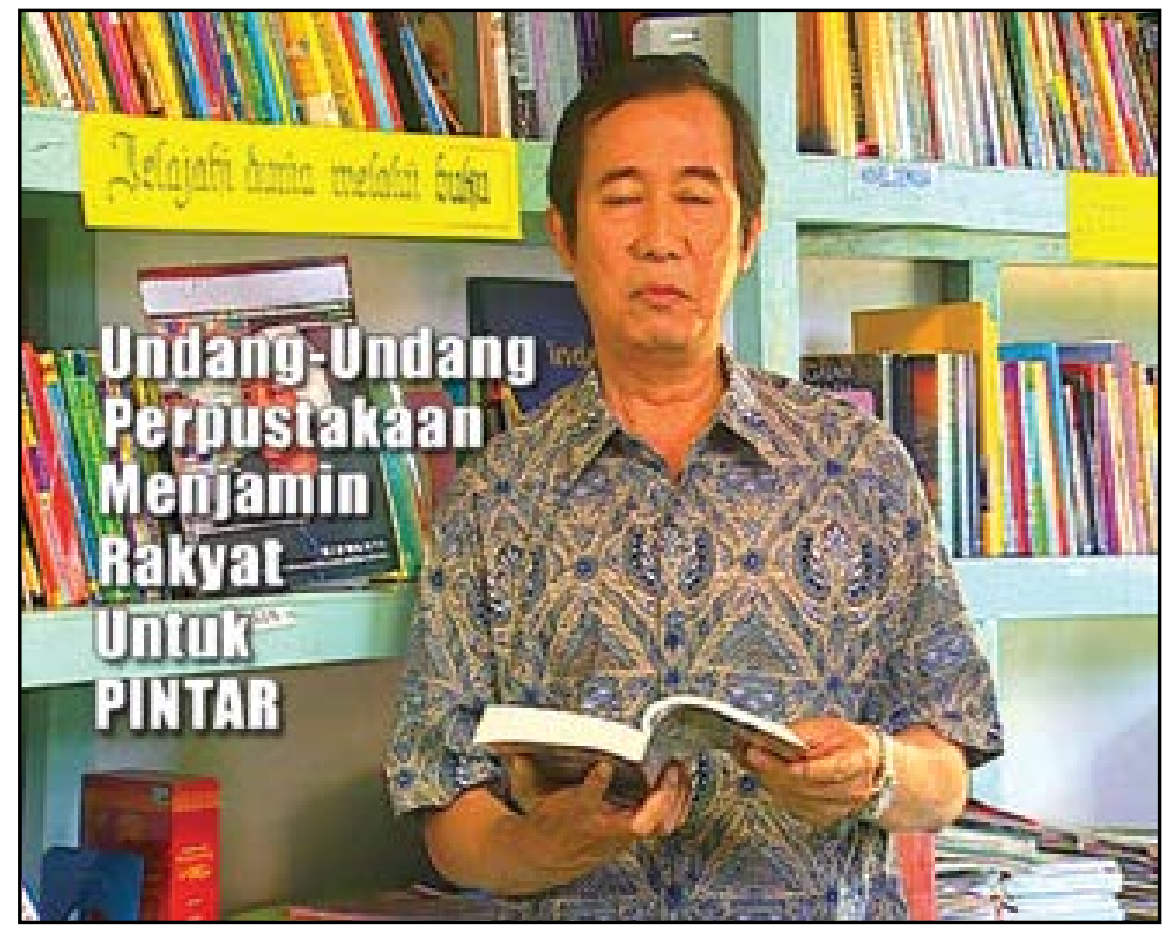

\section{TOKOH}

Kiwil /Undang-undang perpustakaan, 2008

\section{ADEGAN DAN DIALOG}

Adegan 1:

Seorang gadis dewasa berdiri menyenderkan tubuhnya di rak buku, di ruangan perpustakaan, yang mirip taman bacaan. Lalu muncul Kiwil, ia memanggil sambil bertepuk tangan satu kali untuk menarik perhatian, "Hadirin!”

Adegan 2:

Layar terbagi dalam empat frame, yang setiap frame terdapat wajah tiga anak laki-laki dan seorang anak perempuan. Mereka sedang memegang buku, sambil menengok ke kamera.

Adegan 3:

Kiwil melanjutkan: "Sekarang sudah ada payung hukum." Berhenti sejenak. Kamera close-up membidik wajah seorang bocah, dan di layar muncul balon: Brisik!!! Kiwil melanjutkan: "Sudah tahu belum?" Si Gadis yang berdiri bertanya: "Payung hukum?" Di layar muncul balon yang di dalamnya ada gambar payung berwarna hitam dan matahari berwarna kuning.

Adegan 4: 
Seorang ibu berbaju biru bermotif dan berjilbab putih menyahut: "Yang penting mah, anak-anak pinter, bang Kiwil." Di samping kiri layar terdapat tiga frame: gambar anakanak sedang membaca buku sambil berbaring di dahan pohon; gambar gadis dewasa yang sedang membaca; dua anak laki yang duduk di karpet membaca buku.

Adegan 5:

Dady Rahmananta, sambil memegang buku terbuka, berkata: "Undang-undang perpustakaan menjamin rakyat untuk pinter." Seiring dengan ucapannya, di layar muncul tulisan dengan kata-kata yang sama. Di rak di belakangnya terdapat tulisan: Jelajahi Dunia Melalui Buku.

Adegan 6:

Anak-anak, orang dewasa, dan Kiwil berada di bawah kerindangan pohon. Mereka sedang membaca. Di latar belakang ada mobil perpustakaan keliling yang sedang parkir dan membuka jendela mobil lebar-lebar untuk melayani masyarakat. Buku berderet di raknya.

Adegan 7:

Seorang ibu berbaju merah muda berkata: "Manfaatkan perpustakaan." Tangannya kanannya berayun, memunculkan tulisan animasi yang berbunyi frasa yang sama dengan ucapannya.

Adegan 8:

Kamera close-up. Sambil mengacungkan ibu jarinya, Kiwil berkata: "Perpustakaan, sarana pinter buat pinter. Betul?" Di layar, muncul animasi kalimat Kiwil. Kamera longshot. Masyarakat yang berdiri di sekelilingnya menyahut sambil tertawa bersama-sama: "Betuuul." Lalu mereka beramai-ramai menggayuti Kiwil, sehingga ia terbungkuk.

Suara musik menggunakan dentingan piano.

\section{INTERPRETASI}

1. Semantik: Undang-undang perpustakaan sama sekali tidak dikeluarkan; yang menonjol adalah kegiatan membaca oleh anak-anak.

2. Stilistik:

- s.d.a Lihat halaman 82.

- Daya tarik humor untuk menimbulkan perasaan gembira.

3. Sintaksis: Latar menunjang isi pesan yang ingin disampaikan.

4. Retoris: Pengambilan gambar sangat cepat berpindah; lebih variatif dengan gambar balon-balon.

- Antara kata-kata dan gambar tidak ada koherensi.

5. Pesan: Mengajak membaca.

Dari segi stilistik, PNRI menggunakan kata-kata sederhana agar mudah dipahami dan diterima oleh masyarakat. Bahkan seri Bajuri-Oneng menggunakan bahasa Betawi, 
dan diiringi musik tanjidor. Selain itu, seluruh ILM memiliki daya tarik yang menonjolkan emosi seperti gembira, sedih, bergelora. Sebagian besar menggunakan humor untuk menimbulkan perasaan gembira, seperti dalam seri Bajuri-Oneng, Tukul, dan Kiwil. Humor yang dibawakan oleh para komedian tersebut, menurut para informan, kurang dapat menggelitik rasa geli. Teknik persuasif lainnya ada di dalam seri Tamara. Ia menggunakan kata ganti orang ketiga jamak kita, sehingga dapat melibatkan pemirsa.

Dari segi retoris dalam ketujuh ILM tersebut, menurut informan dari PNRI, hanya seri Tukul yang gagal dalam pengemasan gambar. Iklan tersebut dikritik menggunakan alur yang tidak mengalir sehingga pesannya sulit ditangkap. Retoris juga dapat dilihat dari ekspresi para pemainnya. Ketujuh ILM lumayan baik mengungkapkan ekspresi tersebut, seperti gadis yang tinggal di daerah kumuh yang membutuhkan buku, ia dapat mengekspresikan wajah sedih dan gembira, atau gadis yang bingung saat Kiwil mengatakan payung hukum. Hanya ekspresi Dady yang terlihat sangat kaku. Dalam dua adegan di dua seri, ia berdiri tegak sambil membawa buku terbuka, berbicara, dan mengacungkan ibu jari. Padahal, ia mewakili citra PNRI, yang sebaiknya dapat berekspresi ramah untuk membujuk pemirsa datang ke lembaga tersebut.

Pesan berikutnya menyatakan bahwa membaca itu penting untuk meningkatkan taraf hidup. Jika rajin membaca, seseorang akan sukses. Pesan tersebut muncul dalam versi Marshanda, yang melakukan monolog: "Mau tahu rahasia sukses? Selalu belajar dan rajin baca." Kata sukses berkaitan erat dengan upaya peningkatan taraf hidup. Iklan dengan tokoh utama dan para figuran yang berusia remaja menunjukkan bahwa target iklan tersebut adalah untuk memotivasi generasi muda agar berkarya dan berprestasi. Pesan lainnya adalah bahwa membaca dapat di mana saja dan merupakan kegiatan yang menyenangkan bagi seluruh lapisan masyarakat, mulai dari orang muda hingga tua, pelajar, ibu dan bapak rumah tangga, hingga pengemis, bahkan mereka yang tunanetra.

Pesan berikutnya yang ingin disampaikan oleh PNRI adalah bahwa lembaga tersebut dekat dengan pusat kekuasaan. Kedekatan tersebut memudahkan perpustakaan dalam menjalankan operasionalnya dan menjadi jaminan bagi eksistensi PNRI. Versi Bajuri menyatakan dengan gamblang bahwa mobil untuk operasional perpustakaan keliling merupakan bantuan dari pemerintah. Versi SBY menayangkan gambar Presiden SBY yang menunjukkan hubungan dekat tersebut.

\section{b. Analisis praktik wacana}

Proses produksi dan konsumsi teks menunjukkan bahwa PNRI lebih menonjolkan promosi lembaganya, dibandingkan substansi ILM. Proses produksi yang dipimpin oleh Indra, nama samaran untuk staf yang bekerja di PNRI dan juga sebagai kreator iklan itu sendiri, mencerminkan cara organisasi bekerja dan cara mereka memandang suatu fenomena.

Dalam penyeleksian artis dan munculnya tokoh pejabat, yaitu Kepala Perpustakaan 
dan Kepala Negara, PNRI lebih menonjolkan aspek selebritis para tokoh daripada aspek kebiasaan membaca mereka. Dari deretan artis, hanya Rieke yang memiliki pendidikan pascasarjana dan sudah menerbitkan buku, yang semuanya sudah pasti dilakukannya lewat kebiasaan membaca buku, dan reputasi Tantowi yang selalu menjadi presenter pada acara-acara yang berkaitan dengan intelektualitas. Pada kenyataannya, artis yang punya kebiasaan membaca memang jarang. Dengan gaya hidup masyarakat saat ini dan latar belakang pendidikan yang kurang menekankan makna pentingnya membaca, serta program televisi sehari-hari yang banyak menyajikan tayangan sinetron, perhatian masyarakat lebih terfokus pada pesona para artis. Artinya, pesan bahwa membaca itu penting karena dapat meningkatkan taraf hidup, tertutup oleh bayang-bayang kecermelangan si artis. Indra sendiri mengakui bahwa mereka memilih tokoh ILM berdasarkan kepopuleran. Bukan hanya karena Presiden SBY dan istrinya membangun perpustakaan keliling, tetapi juga karena posisi mereka yang sedang memegang kekuasaan. Meskipun demikian, gagasannya untuk ILM tahun 2009 berbeda dengan konsep iklan-iklan sebelumnya. Ia memanfaatkan anak-anak dari setiap provinsi di Indonesia, bermonolog dengan bahasa asli mereka. Tujuannya adalah agar ILM tersebut dapat menyentuh lebih banyak masyarakat di daerah.

Kreator iklan sangat berperan dalam sukses tidaknya pesan yang disampaikan dalam ILM kepada sasaran. Dari hasil wawancara, terungkap bahwa Indra memiliki pengetahuan yang cukup banyak tentang seluk-beluk iklan dari hasil interaksinya saat berurusan dengan proses pembuatan iklan. Ia bercerita bahwa selama membuat ketujuh iklan tersebut, gagasannya selalu disetujui oleh 11 anggota tim produk PNRI, yang menguji dan mengambil keputusan untuk segala jenis produk dan jasa yang akan dipublikasikan. Hal tersebut terjadi karena prestasi Indra di bidang kehumasan atau karena tulisannya ada di mana-mana.

Konsumsi teks meliputi bagaimana masyarakat menginterpretasi, merespon, membicarakan, dan mendiskusikan teks iklan yang dimaksud. Semua informan memberikan respons positif terhadap iklan-iklan tersebut. Mereka memahami pesan yang disampaikan oleh iklan tentang perpustakaan. Kaitan antara membaca dan kesuksesan terbatas pada pendapat umum. Membaca adalah kegiatan praktis untuk menambah wawasan dan membantu menyelesaikan tugas dari sekolah. Menurut mereka, membaca dapat menambah pengetahuan dan wawasan. Pemahaman mereka belum sampai pada konsep bahwa membaca dapat memberdayakan daya analisis (Elkin 2003). Masyarakat belum dapat menangkap bahwa daya analisis dalam kognisi manusia diperlukan untuk memahami realitas kehidupan yang nyata, untuk memilah-milah prioritas hidup, untuk memahami makna suatu kebahagiaan dan penderitaan, untuk memahami dan menginterpretasi konsep diri dalam interaksi dan tindakan manusia lain.

Masyarakat yang mendapatkan informasi dan pengetahuan cenderung mengabaikan buku, tetapi lebih condong melalui televisi, teman, keluarga, atau 
pengalaman hidup, browsing di internet, ceramah di masjid, menonton motivator di televisi, tempat kursus. Mereka tidak ke perpustakaan, karena bagi mereka perpustakaan hanya bagi mereka yang sedang sekolah. Dalam versi Marshanda, ia perlu membaca buku, sebab ia sedang kuliah. Untuk kepentingan pekerjaannya, ia tentunya harus membaca buku yang berkaitan dengan cara berakting dan menyanyi yang baik, sehingga ia akan mencapai sukses untuk pendidikan dan kariernya. Demikian pula dengan siswa dan mahasiswa, mereka menggunakan perpustakaan karena tuntutan tugas.

Lebih jauh lagi, mereka tidak pernah menyaksikan iklan-iklan tersebut di layar televisi dan baru kali ini mereka menontonnya. Hampir seluruh informan belum pernah menonton iklan-iklan tersebut di televisi. Mereka baru menontonnya ketika penelitian dilakukan. Hal tersebut tentunya disebabkan oleh jam tayang yang tidak tepat atau iklan yang tidak menarik sehingga luput dari perhatian. Penayangan ILM hanya di empat stasiun televisi, dengan jam tayang di pagi hari, saat anak-anak sekolah dan orang dewasa bekerja di kantor, dan malam hari pada jam 10 atau 11 malam, bahkan jam 2 dini hari, waktu yang digunakan untuk tidur oleh kebanyakan masyarakat. Menurut Indra, pihak televisi memberikan tayangan dini hari di sela-sela pertandingan sepak bola adalah sebagai bonus.

Pada saat menonton ILM produksi PNRI, sebagian besar dari mereka merasa bosan. Mereka tertarik ketika tokoh yang membintanginya artis cantik Marshanda dan Tamara. Keduanya dianggap artis yang hobi membaca, dan yang pada waktu itu, jauh dari gosip miring. Iklan yang dibintangi oleh Dady, kepala PNRI, dianggap tidak menarik, karena terasa kaku, kurang kreatif, dan kurang mengundang, meskipun pesannya mudah dicerna. Fakta ini menunjukkan bahwa PNRI belum sepenuhnya memahami bagaimana berinteraksi dengan masyarakat melalui media iklan televisi. Indra menyatakan bahwa memang belum pernah dilakukan evaluasi terhadap ILM-ILM yang ada. Tim pembuat iklan juga tidak pernah melakukan riset pasar, riset media, riset masyarakat, dan riset mengenai iklan-iklan itu sendiri, padahal kegiatan tersebut sangat diperlukan (Lee \& Johnson 1999, 133).

\section{c. Analisis sosiokultural}

Analisis sosiokultural bertujuan mengungkap realitas sosial dari suatu fenomena. Realitas sosial yang terungkap dalam iklan ini adalah bahwa kampanye tersebut belum diterima masyarakat sasaran. Antara PNRI, masyarakat, dan stasiun televisi terhalang oleh perbedaan nilai. Bagi masyarakat, artis adalah individu yang hidup di alam khayalan dengan segala sifat glamour mereka. Seri Marshanda dengan jelas menawarkan kehidupan kosmopolitan yang serba sibuk. Meskipun mereka membangun karier dari bawah, masyarakat tidak melihat hal itu sebagai teladan, dan tetap menganggap bahwa dunia mereka sangat berbeda. Penggunaan artis malah membuat jarak antara masyarakat dan PNRI. Ketika yang menyampaikan pesan adalah seorang komedian (Tukul, Kiwil, 
dan Bajuri), ILM tersebut malah membingungkan pemirsa, apakah pesan ILM serius atau gurauan.

Demikian pula dengan pemakaian figur pejabat. Menurut Wiryoutomo (2008), ILM merupakan gambaran perilaku pejabat pemerintah yang umumnya mengarahkan, berkomunikasi secara top-down, menggunakan kata-kata seorang pejabat. Dari sekian ILM, ia hanya teringat pesan pejabat Kepala Perpustakaan Nasional: "Perpustakaan, cara pinter untuk jadi pintar", dan bukannya pesan bahwa membaca itu penting.

Realitas sosial lainnya adalah bahwa rasa percaya masyarakat kepada PNRI sangat rendah. Masyarakat memang belum menganggap perpustakaan mau pun kegiatan membaca sebagai sesuatu yang penting. Mereka memiliki keyakinan bahwa PNRI, sebagai lembaga tempat sekumpulan buku, belum tentu memiliki buku yang dicari. Seperti yang dikatakan oleh seorang informan, "Lebih baik membeli buku sendiri daripada repot-repot ke perpustakaan." Sebagian besar dari informan adalah mereka yang jarang dan bahkan tidak pernah ke perpustakaan. PNRI dianggap sebagai kantor birokrat, tempat para pejabat, sehingga mereka berasumsi bahwa suasananya akan tidak senyaman yang diinginkan. PNRI juga tidak mampu mengadaptasi kepentingan komersial dari empat stasiun teve terkait. Dapat disimpulkan bahwa pihak PNRI tidak dapat memberi keyakinan yang pasti kepada masyarakat dan stasiun televisi bahwa mereka sedang mengampanyekan sesuatu yang serius untuk keberlangsungan hidup masyarakat banyak.

\section{KESIMPULAN}

Kajian tujuh ILM produksi PNRI menunjukkan bahwa pesan yang disampaikan kurang dapat dipahami oleh hampir sebagian besar informan. Dari fakta tersebut terlihat adanya perbedaan nilai dan kepentingan antara lembaga dan masyarakat sasaran. Masyarakat memiliki keyakinan bahwa untuk dapat mencapai kesuksesan, mereka harus bekerja keras, bukan membaca buku. Untuk menambah pengetahuan dan wawasan, mereka dapat memperolehnya dari teman, keluarga, ceramah agama, atau siaran televisi. Masyarakat belum memiliki konsep pendidikan dan pentingnya buku dan perpustakaan bagi kehidupan mereka. Ketidakpedulian masyarakat terhadap ILM produksi PNRI merupakan cerminan rasa tidak percaya terhadap lembaga tersebut. Sementara itu, PNRI kurang menekankan substansi ILM, karena lebih memfokuskan diri pada tujuan mempromosikan lembaga.

Sebuah saran sederhana yang dapat disampaikan adalah perbaikan proses pembuatan iklan. Lembaga yang ingin menyampaikan pesan yang bersifat abstrak sebaiknya menyajikan proses secara perlahan dan rinci. PNRI perlu mengenal masyarakat, mencakup kebiasaan hidup, cara memperoleh pengetahuan, pandangan mereka tentang buku dan perpustakaan, bagaimana mereka menghabiskan waktu luang. Konsep bahwa membaca dapat menjadikan kita sukses perlu disampaikan dalam teknik bercerita, yang 
dapat ditayangkan dalam beberapa sekuel iklan. Dengan demikian masyarakat mendapat waktu yang cukup untuk proses pemahaman dan pengendapan atas makna membaca dan pentingnya konsep pendidikan dan perpustakaan.

\section{DAFTAR ACUAN}

Altstiel, Tom and Jean Grow. Advertising strategy: creative tactics from the outside/In. London: SAGE. 2006.

Askew, Kelly and Richard R. Wilk, eds. Anthropology of media: a reader. Massachusets: Blackwell. 2002.

Djachra, Ida R. "Mengapa siswa malas berkunjung ke perpustakaan?" Pikiran Rakyat, 2 Maret. Teropong pendidikan kita: antologi artikel 2005-2006. Edisi 1. Jakarta: Pusat Informasi dan Humas, Depdiknas. 2006.

Elkin, Judith, Briony Train, and Debbie Denham, eds. Reading and reader development: the pleasure of reading. London: Facet. 2003.

Eriyanto. Analisis wacana. Yogyakarta: LKiS. 2001.

Fairclough, Norman. Media discourse. London: Edward Arnold. 1995.

Gay, Paul du, Stuart Hall, Linda Janes, Hugh Mackay, and Keith Negus. Doing cultural studies: the story of the Sony Walkman. London: SAGE. 1997.

Jain, Abbinandan K., Ashok Jambbekar, T.P. Rama Rao dan Sreenivas Rao (red.). Marketing information products and services: a primer for librarians and information professionals. Ottawa: International Development Research Centre. 1999.

Lee, Monle dan Carla Johnson. Prinsip-prinsip pokok periklanan dalam perspektif global. Diterjemahkan oleh Haris Munandar dan Dudy Priatna. Edisi 1. Jakarta: Prenada. 2004.

Robertson, Deborah A. Cultural programming for libraries: linking libraries, communities, and Culture. Chicago: the American Library Association. 2005.

Titscher, Stefan, Michael Meyer, Ruth Wodak dan Eva Vetter (red.). Methods of text and discourse analysis. Diterjemahkan oleh Bryan Jenner. London: SAGE. 2000.

Wiryoutomo, Pracoyo. Efektivitas Iklan Layanan Masyarakat. Koran Tempo. http:// www.korantempo.com. 2008. 